\title{
25. THE $\delta^{18} O$ AND $\delta^{13}$ C ISOTOPIC COMPOSITION OF SECONDARY CARBONATES FROM BASALTIC LAVAS CORED IN HOLE 642E, OCEAN DRILLING PROGRAM LEG 1041
}

\author{
David A. Love, ${ }^{2,3}$ S. K. Frape, ${ }^{2}$ Ian L. Gibson, ${ }^{2}$ and M. G. Jones ${ }^{2}$
}

\begin{abstract}
Hole 642E is located near the outer margin of the Vøring Plateau in the Norwegian Sea. The thick pile of basaltic lavas penetrated during drilling are variably altered with extensive development of calcite, which fills vesicles and fractures along with saponite and celadonite. $\delta{ }^{13} \mathrm{C}$ results, determined by mass spectrometry, show that most carbonates above about $1040 \mathrm{~m}$ have values between -2.5 and $-5.5 \%$ (PDB), but a few samples at approximately $1090 \mathrm{~m}$ have depleted $\delta{ }^{13} \mathrm{C}$ values down to $-26.3 \%$. Below $1100 \mathrm{~m}$ the $\delta{ }^{13} \mathrm{C}$ values decrease from $-6.0 \%$ to $-12 \%$. The $\delta{ }^{18} \mathrm{O}$ values range between -1.9 and $-13.7 \%$ (PDB), and generally decrease with depth. The results are interpreted as indicating that the calcites were precipitated from cool seawater percolating through the basalt pile at water:rock of less than 10:1, during seawater incursion at about $54 \mathrm{Ma}$. The progressive depletion with depth may result from subsequent reequilibration at temperatures below those of formation, and the geothermal gradient on the Vøring Plateau appears to have decreased with time. The very depleted values of $\delta^{13} \mathrm{C}$ for carbonates around the $1090-\mathrm{m}$ level are probably related to organic matter from an underlying volcaniclastic unit.
\end{abstract}

\section{INTRODUCTION}

Hole 642E, drilled during Leg 104 of the Ocean Drilling Program, is located near the outer margin of the Vøring Plateau in the Norwegian Sea. One of the primary objectives of the Leg was to examine a thick dipping series of lavas which were erupted just before, or during, the initial stages of the formation of the Norwegian Sea (Eldholm, Thiede, and Taylor, 1987; Mutter et al., 1982; Talwani et al., 1983, Hinz et al., 1984). This objective was achieved, and Hole 642E penetrated a 914-m succession of lavas below a $315-\mathrm{m}$ thick cover of Cenozoic hemipelagic sediments. These lavas constitute the easternmost edge and stratigraphically lowest part of the very much thicker Vøring Plateau dipping reflector lava pile (Shipboard Scientific Party, 1986).

The lavas are variably altered with extensive development of calcite, which generally fills vesicles and fractures in the flows and is the most abundant nonsilicate secondary mineral. In an attempt to learn more of the posteruptive history of the lava pile, particularly secondary alteration, we have examined the carbon and oxygen isotopic composition of 20 calcite samples taken throughout the core. The objective was to determine whether subaerial secondary mineralization, comparable to that found in present-day Iceland, affected the flows prior to submergence and burial.

\section{GEOLOGICAL RELATIONS AND SAMPLING}

The basement lithology is well described in Shipboard Scientific Party (1987), and the following summary is from that account. The volcanic succession cored in Hole 642E is divided into two series: a 763-m thick upper series, comprising approximately 122 tholeiitic basalt flows and 53 intercalated volcaniclastic sediment horizons; and a 143-m thick lower series, containing 16

\footnotetext{
${ }^{1}$ Eldholm, O., Thiede, J., Taylor, E., et al., 1989. Proc. ODP, Sci. Results, 104: College Station, TX (Ocean Drilling Program).

2 Dept. of Earth Sciences, University of Waterloo, Waterloo, Ontario, Canada N2L $3 \mathrm{G} 1$.

${ }^{3}$ Current address: Dept. of Geological Sciences, Queen's University, Kingston, Ontario, Canada, K7L 3N6.
}

flows of peraluminous andesite and basalt, which are sometimes glassy, 4 dikes, and 7 volcaniclastic layers including a 5 -m thick ignimbrite. A red-brown eutaxitic tuff and mudstone (Unit S43) which is at least $7 \mathrm{~m}$ thick separates the upper and lower series. The upper series has two varieties of flows, thick (average $8 \mathrm{~m}$ ) fine-grained lavas and thin (average $3.3 \mathrm{~m}$ ) medium-grained lavas, which are similar chemically. The fine-grained flows have a distinct textural zonation whereas the medium-grained flows are texturally more uniform. The upper series flows are mostly subaerial, and red, weathered, brecciated to scoriaceous flow tops are common throughout. In contrast, except for the uppermost horizon (Unit S43), red weathered horizons are absent in the lower series.

Throughout the upper series, carbonate occurs in vesicles and fractures along with saponite and celadonite. Calcite is the most abundant open space-filling carbonate mineral. Vesicles are often zoned, having saponite rims and calcite cores and an intervening zone of celadonite. Sometimes the celadonite and calcite are intergrown. There is distinct zonation of vesicles within finegrained flows, and some zonation of vesicles in medium-grained flows, but there is no relationship between the presence or abundance of vesicle-filling carbonate minerals and the internal characteristics of the flows. Nor is there any relationship between vesicle-filling carbonate minerals and the red alteration at the tops of some flows (Shipboard Scientific Party, 1987). The lowest $50 \mathrm{~m}$ of the upper series has red-brown staining associated with ferroan calcite in fractures and vesicles.

In the lower series, alteration is a little more extreme; parts of some flows are bleached white, and volcaniclastic rocks contain zeolites and secondary silica as well as small amounts of carbonate. Carbonate postdates silica and is less abundant in fracture and vesicles.

The physical nature of the carbonate in the upper and lower series is the same. The carbonate is most often equant, granular crusts of orthosparite on saponite or celadonite, and very rarely coats fracture vesicle walls. Many of the vesicles in the upper series are only partly filled, but carbonate-bearing vesicles tend to be completely filled, although there are a few partially filled ones which have isopachous equant granular spar crusts. Smectiterimmed, unfilled vesicles can occur adjacent to carbonate-filled ones. In some places it is obvious that smaller vesicles are com- 
pletely smectite-filled, whereas larger ones have successive smectite and carbonate.

Fractures that were not broken open during drilling are all completely filled, having saponite rims and often carbonate cores. The carbonate in fractures varies from massive equant granular spar to fibrous and/or bladed crusts which grew to completely fill the fracture. It is virtually impossible to tell whether broken fractures were completely filled. Minor amounts of bright, light green celadonite, and rarely, dull olive green saponite are intergrown with equant granular spar in the fractures. Some fractures have distinctive cores of gray-green $(\mathrm{Mg}$ ?) saponite surrounded by carbonate, and rims of dark green (Fe?) saponite. The mineralogy, chemistry, and isotopic contents of the secondary clay minerals in Hole $642 \mathrm{E}$ are described in detail in Desprairies et al. (this volume) and LeHuray and Johnson (this volume).

Very rarely, intergranular carbonate is found in the flow matrix; for example, in Sections 104-642E-94-3, $34 \mathrm{~cm}$, and $-94-3,101 \mathrm{~cm}$. Sulfides are never found in vesicles, but occur rarely in fractures; for example, in Sections 104-642E-17-2, 77 $\mathrm{cm}$, and $-94-2,141 \mathrm{~cm}$.

Geopetal textures in vesicles are uncommon but do occur throughout the upper series. In most cases the spar fills the remaining open space after geopetal smectite. Very rarely does the spar itself appear geopetal, as in Sections 104-642E-17-2, 28 $\mathrm{cm}$; and here, although the spar is certainly not isopachous, it may not be geopetal.

Many of the vesicles and fractures sampled for carbonate are rimmed with a dark green smectite, probably saponite. In some cases carbonate and celadonite are intergrown. Carbonate was scraped from fractures and vesicles using a small hand-held grinder and stainless-steel dental tools. Care was taken during sample preparation to include as little of the clay minerals as possible in the carbonate sample. The style of carbonate mineralization is noted in Table 1 .

\section{EXPERIMENTAL PROCEDURES}

Carbon and oxygen as $\mathrm{CO}_{2}$ were extracted from 30 - to 50-mg calcite samples by treatment of the calcite with $100 \%$ phosphoric acid at $50^{\circ} \mathrm{C}$

Table 1. Analytical results and style of mineralization: Section $=$ core section, interval $(\mathrm{cm}), \mathbf{V}=$ vesicle-filling, $\mathbf{F}=$ fracture-filling.

\begin{tabular}{lccccc}
\hline Section & $\begin{array}{c}\delta^{13} \mathrm{C}_{\mathrm{PDB}} \\
\left(\%_{00}\right)\end{array}$ & $\begin{array}{c}\delta^{18} \mathrm{O}_{\mathrm{PDB}} \\
\left(\%_{00}\right)\end{array}$ & $\begin{array}{c}\delta^{18} \mathrm{O}_{\mathrm{SMOW}} \\
\left(\%_{0}\right)\end{array}$ & $\begin{array}{c}\text { Depth } \\
(\mathrm{mbs})\end{array}$ & Style \\
\hline $\begin{array}{l}\text { Upper series } \\
\text { (104-642E-) }\end{array}$ & & & & & \\
$9-2,19$ & -5.13 & -3.25 & 27.5 & -367.47 & $\mathrm{~V}$ \\
$17-1,32$ & -4.70 & -4.71 & 26.0 & -424.62 & $\mathrm{~V} \& \mathrm{~F}$ \\
$17-1,128$ & -3.26 & -6.00 & 24.7 & -425.58 & $\mathrm{~V} \& \mathrm{~F}$ \\
$17-2,77$ & -5.53 & -4.04 & 26.7 & -426.57 & $\mathrm{~F}$ \\
$18-2,72$ & -4.00 & -3.46 & 27.3 & -435.42 & $\mathrm{~F}$ \\
$25-4,3$ & -4.84 & -6.09 & 24.6 & -496.54 & $\mathrm{~V}$ \\
$26-4,28$ & -4.31 & -4.83 & 25.9 & -506.58 & $\mathrm{~F}$ \\
$41-3,15$ & -2.53 & -1.88 & 28.9 & -644.30 & $\mathrm{~V}$ \\
$41-3,17$ & -2.52 & -2.10 & 28.7 & -644.32 & $\mathrm{~V}$ \\
$64-2,74$ & -2.48 & -2.81 & 28.0 & -814.71 & $\mathrm{~V}$ \\
$85-1,110$ & -4.47 & -6.23 & 24.4 & $-998.70 *$ & $\mathrm{~V}$ \\
$94-2,141$ & -16.72 & -9.20 & 21.4 & -1085.54 & $\mathrm{~F}$ \\
$94-3,34$ & -26.26 & -9.25 & 21.3 & $-1085.97 *$ & $\mathrm{~F}$ \\
$94-3,101$ & -21.35 & -8.16 & 22.4 & -1086.74 & $\mathrm{~V}$ \\
Lower series & & & & & \\
$(104-642 \mathrm{E}-)$ & & & & & \\
$98-1,147$ & -6.38 & -9.33 & 21.8 & $-1117.27 *$ & $\mathrm{~V}$ \\
$98-2,16$ & -6.02 & -8.71 & 21.9 & -1117.46 & $\mathrm{~F}$ \\
$102-1,126$ & -5.58 & -4.24 & 26.5 & -1154.76 & $\mathrm{~F}$ \\
$107-2,73$ & -9.14 & -13.74 & 16.7 & -1193.63 & $\mathrm{~F}$ \\
$109-1,56$ & -11.79 & -12.39 & 18.1 & -1210.96 & $\mathrm{~V}$ \\
$110-1,39$ & -11.38 & -13.65 & 16.8 & -1220.29 & $\mathrm{~F}$ \\
\hline
\end{tabular}

- Mean of two replicate determinations using a method modified from McCrea (1950). The ${ }^{13} \mathrm{C}$ and ${ }^{18} \mathrm{O}$ were then determined directly using a semiautomated V.G. Micromass 903 triple-collecting mass spectrometer. All the isotopic data are reported using the standard $\delta$ notation relative to the Peedee belemnite (PDB) standard for carbon and oxygen, and also the SMOW (standard mean ocean water) standard for oxygen. Isotopic analyses of replicates demonstrated that the analytical uncertainty was less than \pm 0.2 for $\delta{ }^{18} \mathrm{O}$ and \pm 0.1 for $\delta{ }^{13} \mathrm{C}$.

\section{RESULTS}

The isotopic results are given in Table 1, and plots of the data are shown in Figures 1 and 2. Table 1 shows that there is no systematic difference between the isotopic content of vesicle and fracture carbonates.

The $\delta{ }^{13} \mathrm{C}$ results (Fig. 1A) suggest a bimodal grouping of the carbonates. Most vesicles and fracture fillings in the upper part of the core, above about $1040 \mathrm{~m}$, have values between -2.5 and $-5.5 \%$ (PDB). At approximately 1085 to $1090 \mathrm{~m}$ several samples with very depleted $\delta{ }^{13} \mathrm{C}$ values were found; the most depleted samples in this group have values of $-26.3 \%$. Below $1100 \mathrm{~m}$ the $\delta{ }^{13} \mathrm{C}$ values gradually decrease from $-6.0 \%$ to values close to $-12 \%$.

The $\delta{ }^{18} \mathrm{O}$ values range between -1.9 and $-13.7 \%$ (PDB), and generally have steadily decreasing values with depth (Fig. 1B).

\section{DISCUSSION}

There is little textural or geological evidence concerning the origin of the carbonate minerals in Hole 642. The absence of any relationship between vesicle-filling carbonate materials and the red alteration at the tops of some flows suggests that calcite occurrence is not directly related to subaerial exposure. Geopetal textures of carbonate vesicle fillings can be interpreted as indicators of precipitation from meteoric water in the vadose zone, but these textures are very rare in Hole 642E and uncertainty remains as to whether they are truly geopetal or simply nonisopachous crusts. Partly-filled vesicles having isopachous equant granular spar crusts on saponite or celadonite persist throughout the hole, indicating only that most of the carbonate was precipitated in the phreatic zone.

The ferroan calcite in the lowest $50 \mathrm{~m}$ of the upper series is unusual in that it comes from thin veins bordered on each side by pronounced narrow zones of red-brown discoloration. No analytical work has been attempted here to measure the chemical changes involved in the discoloration process. However, the most likely explanation is that iron was enriched in local solutions, resulting in formation of ferroan calcite in the fractures and probably ferric hydroxides in the discolored zone.

\section{OXYGEN ISOTOPES}

Hattori and Muehlenbachs (1982) analyzed the oxygen and carbon isotopic compositions of calcites from a series of boreholes in three areas in Iceland. The results are summarized in Table 2. Samples are from depths to $3 \mathrm{~km}$ and the rocks penetrated by the boreholes range in age from Holocene to about 10 Ma. The Icelandic basalts are, in general, very comparable in composition to the subaerial flows of the upper series of Hole 642E (Shipboard Scientific Party, 1987; Viereck et al., this volume). However, Table 2 shows that the Icelandic calcites have much lower $\delta{ }^{18} \mathrm{O}$ compositions. Hattori and Muehlenbachs (1982) suggested that these low $\delta{ }^{18} \mathrm{O}$ values resulted from the precipitation of calcite at 300 to $400^{\circ} \mathrm{C}$ from seawater at Reydarfjordur and Reykjavik and from meteoric waters with low $\delta{ }^{18} \mathrm{O}$ values at Krafla. In contrast the $\delta{ }^{18} \mathrm{O}$ compositions of secondary vein and replacement calcites precipitated from seawater at low temperatures in submarine ocean floor basalts are comparable to the results from the subaerial flows from Hole $642 \mathrm{E}$ (see, for example, Muehlenbachs, 1977). 

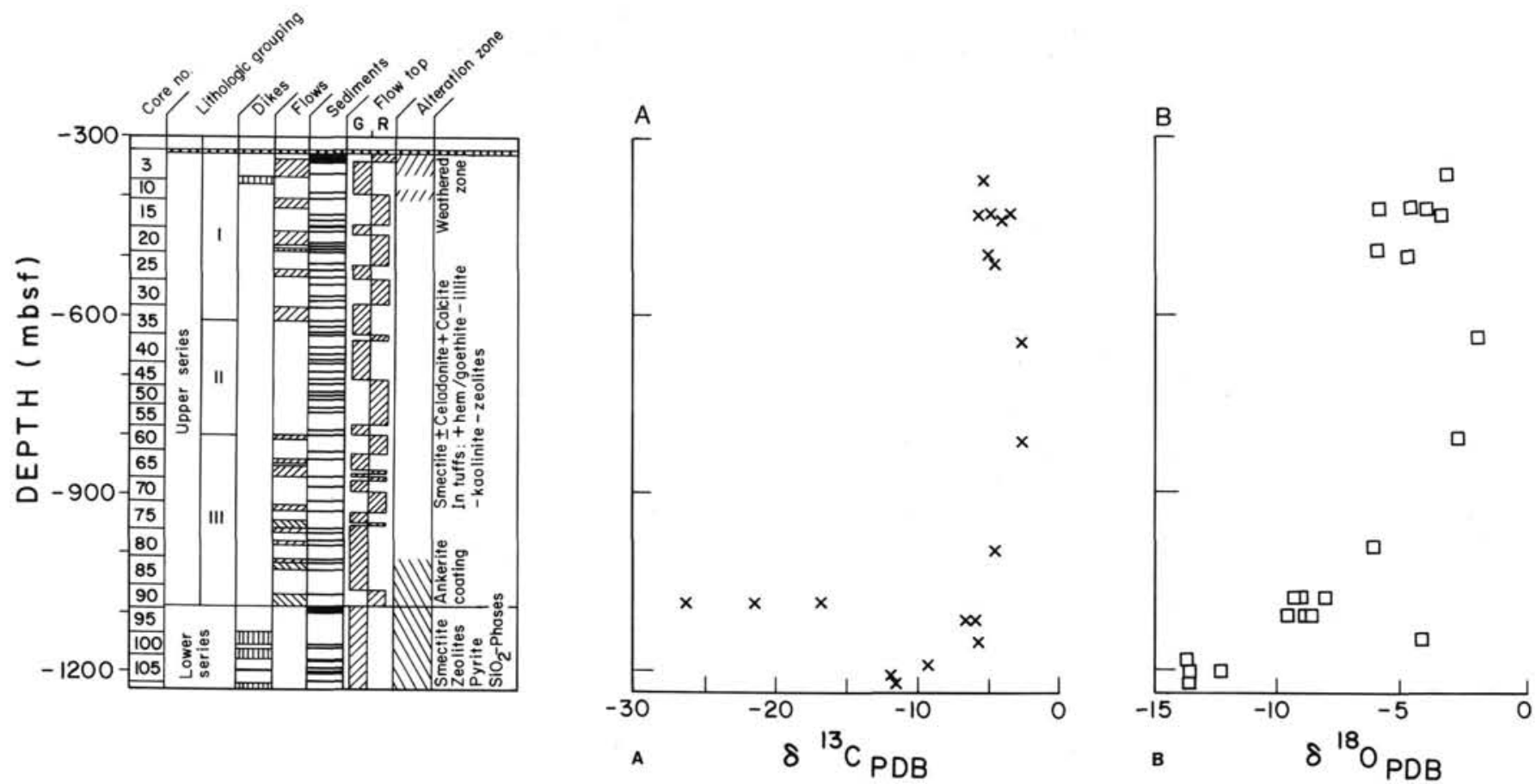

Figure 1. The isotopic contents of contained secondary carbonates compared with the lithostratigraphy and alteration of the volcanic rocks in Hole 642E: A. plot of $\delta{ }^{13} \mathrm{C}$ vs. depth (mbsf), and B. plot of $\delta{ }^{18} \mathrm{O}$ vs. depth. Flows: no ornament = fine-grained; right-slanting hatching $=$ mediumgrained; left-slanting hatching $=$ mixed. Flow tops: $\mathrm{G}=$ gray, $\mathrm{R}=$ reddened. Alteration: no ornament $=$ low-temperature mineral replacement; right-slant hatching $=$ highly weathered zone; left-slant hatching $=$ zeolitic zone.

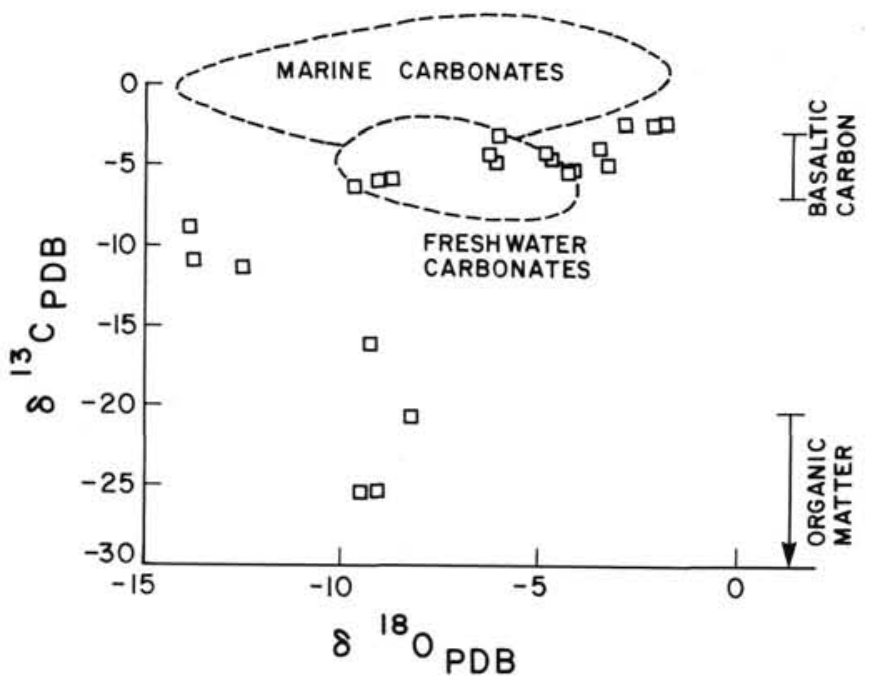

Figure 2. Plot of $\delta{ }^{13} \mathrm{C}$ vs. $\delta{ }^{18} \mathrm{O}$ for secondary carbonates in basalts from Hole $642 \mathrm{E}$, showing the normal compositional ranges of seawater carbonates, freshwater carbonates, organic matter, and mafic igneous rocks.

Table 2. Isotopic composition of Icelandic calcites. Data from Hattori and Muehlenbachs (1982).

\begin{tabular}{lccc}
\hline \multicolumn{1}{c}{ Locality } & $\begin{array}{c}\text { Sample } \\
\text { size } \\
(\mathrm{mL})\end{array}$ & $\begin{array}{c}\delta^{{ }^{13} \mathrm{C}_{\mathrm{PDB}}} \\
(\%)\end{array}$ & $\begin{array}{c}\delta^{{ }^{18} \mathrm{O}_{\mathrm{PDB}}} \\
(\% \circ)\end{array}$ \\
\hline Reydarfjordur & 16 & -4.9 & -24.5 \\
Reykjavik & 6 & -4.9 & -24.0 \\
Krafla & 3 & -4.9 & -37.2 \\
\hline
\end{tabular}

The progressive depletion in the $\delta{ }^{18} \mathrm{O}$ values in carbonates from Hole $642 \mathrm{E}$ probably indicates increasing temperatures of formation with depth. Using the calcite-water fractionation factors of O'Neil et al. (1969), and assuming isotopic equilibrium during formation, we calculated the possible formation temperatures for a variety of water compositions (Table 3 ). The water compositions we used range from a slightly enriched seawater having $\delta{ }^{18} \mathrm{O}$ (SMOW) of $+1.0 \%$ [similar to Honnorez et al. (1985)], to high-latitude meteoric water having $\delta{ }^{18} \mathrm{O}$ of $10.0 \%$ such as in modern day Iceland, where meteoric water ranges between -8 and $-11 \%$ (Arnason, 1976). The calculations include an Eocene seawater composition of $-1.1 \%$ (Savin et al., 1981). The calculated values represent the estimated temperatures of formation of the carbonates or temperatures of later reequilibration, but they are not necessarily the maximum temperatures of burial.

Assuming seawater of $0 \%$ (SMOW) we calculate temperatures of carbonate formation ranging from about $23^{\circ} \mathrm{C}$ near the top of the section, to about $103^{\circ} \mathrm{C}$ at the bottom of the cored section (Fig. 3). The minimum oxygen isotopic composition of the water with which these Hole $642 \mathrm{E}$ calcites equilibrated is $-5.5 \%$ (SMOW). These calcites cannot have formed directly from meteoric water because in the Eocene the Vøring plateau was at high latitudes (Vink, 1984) and meteoric water at such high latitudes would have had much more negative $\delta^{18} \mathrm{O}$ (Taylor, 1979).

To explain the ${ }^{18} \mathrm{O}$ content of the secondary calcites in Hole $642 \mathrm{E}$, we must consider several hypotheses for their formation. They could have formed in equilibrium with any water having $\delta{ }^{18} \mathrm{O}_{(\text {SMOW })}$ greater than $-5.5 \%$. Considering only the oxygen isotopic composition of the calcites, the simplest scenario is that they formed from seawater or slightly evolved seawater, with $\delta{ }^{18} \mathrm{O}$ in the range +1 to $-1 \%$, at approximately the temperatures indicated in Table 3. Alternatively they may have formed at lower temperatures from waters with more negative $\delta{ }^{18} \mathrm{O}$. This potential low-temperature, slightly negative water could 
Table 3. Calculated formation temperatures $\left({ }^{\circ} \mathrm{C}\right)$ for secondary calcites in Hole 642E. Section $=$ core - section, interval $(\mathrm{cm}), \mathbf{w}=$ isotopic composition of water (SMOW).

\begin{tabular}{|c|c|c|c|c|c|c|c|c|}
\hline \multirow{2}{*}{$\begin{array}{c}\text { Section } \\
\text { (104-642E-) }\end{array}$} & \multirow{2}{*}{$\begin{array}{l}\text { Depth } \\
\text { (mbsf) }\end{array}$} & \multicolumn{7}{|c|}{ Temperatures of carbonate formation } \\
\hline & & $w=+1 \%_{0}$ & $\mathrm{w}=0 \%$ & $\mathbf{w}=$ & $-1.1 \%$ & $w=-5.5 \%_{0}$ & $\mathrm{w}=$ & $=-10 \%_{0}$ \\
\hline $9-2,19 \mathrm{~cm}$ & -367.47 & 35 & 29 & & 24 & 5 & & -11 \\
\hline $17-1,32$ & -424.62 & 43 & 37 & & 31 & 11 & & -6 \\
\hline $17-1,128$ & -425.58 & 50 & 45 & & 38 & 17 & & -1 \\
\hline $17-2,77$ & -426.57 & 39 & 34 & & 28 & 8 & & -8 \\
\hline $18-2,72$ & -435.42 & 36 & 30 & & 25 & 6 & & -10 \\
\hline $25-4,3$ & -496.54 & 51 & 45 & & 39 & 17 & & -1 \\
\hline $26-4,28$ & -506.58 & 43 & 38 & & 32 & 12 & & -5 \\
\hline $41-3,15$ & -644.3 & 27 & 23 & & 18 & 0 & & -15 \\
\hline $41-3,17$ & -644.32 & 28 & 24 & & 19 & 1 & $s-$ & -14 \\
\hline $64-2,74$ & -814.71 & 32 & 27 & & 22 & 4 & & -12 \\
\hline $85-1,109$ & -998.69 & 52 & 46 & & 40 & 18 & & 0 \\
\hline $85-1,111$ & -998.71 & 52 & 46 & & 40 & 18 & & 0 \\
\hline $94-2,141$ & -1085.54 & 73 & 65 & & 58 & 33 & & 12 \\
\hline $94-3,34$ & -1085.97 & 75 & 67 & & 60 & 34 & & 13 \\
\hline $94-3,35$ & -1085.98 & 72 & 64 & & 57 & 32 & & 11 \\
\hline $94-3,101$ & -1086.74 & 65 & 58 & & 51 & 27 & & 7 \\
\hline $98-1,147$ & -1117.27 & 71 & 64 & & 57 & 32 & & 11 \\
\hline $98-1,148$ & -1117.28 & 76 & 69 & & 61 & 35 & & 14 \\
\hline $98-2,16$ & -1117.46 & 69 & 62 & & 55 & 30 & & 10 \\
\hline $102-1,126$ & -1154.76 & 40 & 35 & & 29 & 9 & & -7 \\
\hline $107-2,73$ & -1193.63 & 114 & 104 & & 94 & 60 & & 34 \\
\hline $109-1,56$ & -1210.96 & 100 & 91 & & 82 & 51 & & 27 \\
\hline $110-1,39$ & -1220.29 & 113 & 103 & & 93 & 59 & & 33 \\
\hline
\end{tabular}
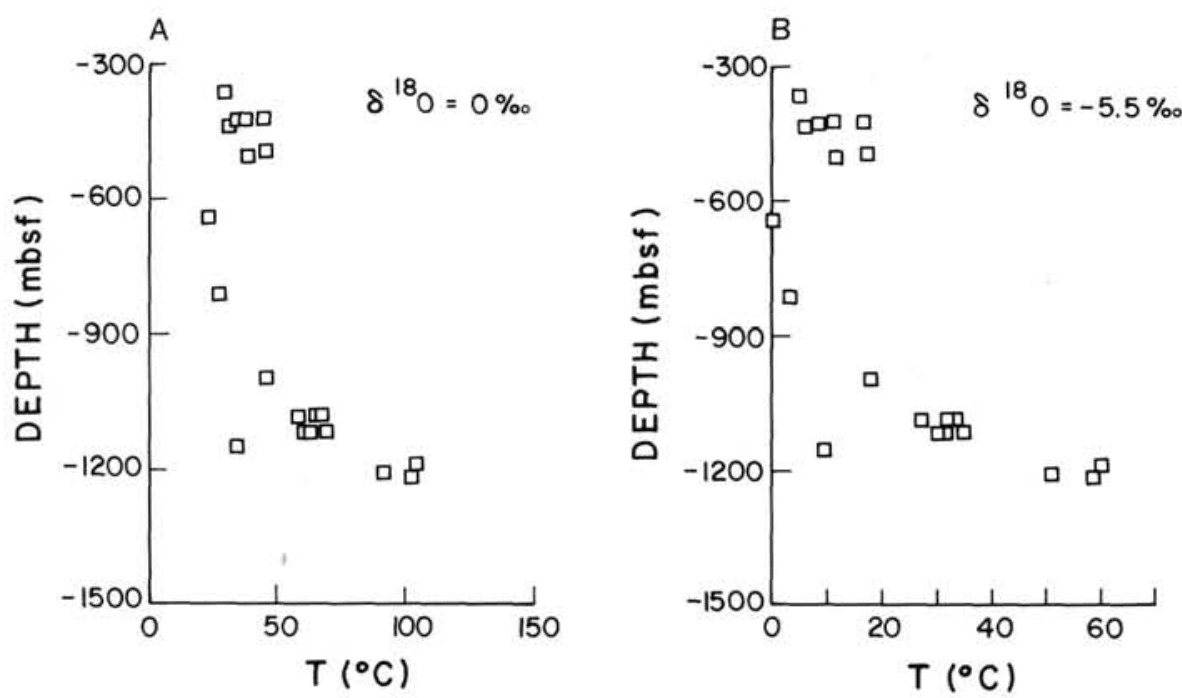

Figure 3. Plot of temperatures of carbonate formation for Hole $642 \mathrm{E}$ secondary carbonates: A. assuming they developed from seawater having $\delta{ }^{18} \mathrm{O}$ of $0 \%$ (SMOW), and $\mathrm{B}$. assuming they developed from water having $\delta{ }^{18} \mathrm{O}$ of $-5.5 \%$ (SMOW).

have been either (a) seawater that had become depleted in ${ }^{18} \mathrm{O}$ through low-temperature interaction with sediments overlying the basaltic oceanic crust (Anderson and Lawrence, 1976; Gieskes et al., 1978; Lawrence et al., 1975; Lawrence et al., 1976; Lawrence and Drever, 1981; Lawrence and Gieskes, 1981; and Hesse, 1986), or (b) connate, originally meteoric, water which through rock - water interaction had evolved to higher ${ }^{18} \mathrm{O}$ contents (Longstaffe, 1983; Hesse, 1986). Finally, the secondary carbonates might have originally formed from meteoric water but subsequently reequilibrated with oxygen in seawater.

Desprairies et al. (this volume) measured the oxygen isotopic composition of secondary saponite and celadonite in Hole 642E. Assuming the coexisting fluid had seawater isotopic composition $(0 \%$ SMOW), they calculate formation temperatures of 35 to $50^{\circ} \mathrm{C}$ for celadonite and 70 to $130^{\circ} \mathrm{C}$ for saponite (op. cit. Table 5). They found that saponite and celadonite in the same samples were not formed together in isotopic equilibrium, the celadonite having formed at lower temperatures or from slightly more negative $\delta{ }^{18} \mathrm{O}$ fluids.

Calculated celadonite-calcite isotope fractionation formation temperatures (Yeh and Savin, 1977), using the celadonite data of Desprairies et al. (this volume), indicate that these two minerals are also not in isotopic equilibrium.

Desprairies et al. calculate celadonite formation temperatures using water of $0 \% 0 \delta^{18} \mathrm{O}_{(S M O W)}$ which are higher than those for adjacent calcite samples. Although celadonite and calcite are intergrown in places, the oxygen in the calcites must have later reequilibrated either at lower temperatures, or with fluids of higher $\delta{ }^{18} \mathrm{O}$, or a combination of both possibilities.

Whiticar and Faber (this volume) found pore waters with $\delta^{18} \mathrm{O}$ as low as $-2.2 \%$ (SMOW) in Hole 642B and as low as $-6.1 \%$ (SMOW) in Hole 642D. If these waters precipitated or 
reequilibrated with the secondary carbonates, then the temperatures involved would be in the range of 0 to $60^{\circ} \mathrm{C}$.

In their study of the $\mathrm{Rb}-\mathrm{Sr}$ systematics in volcanic rocks and alteration minerals from Hole 642E, LeHuray and Johnson (this volume) found that most smectites, celadonites and calcites have seawater-dominated ${ }^{87} \mathrm{Sr} /{ }^{86} \mathrm{Sr}$, and most celadonites have $\mathrm{Rb} / \mathrm{Sr}$ ages of about $54 \mathrm{Ma}$. Some of the celadonites have much younger ages, $26 \mathrm{Ma}$, which indicate an Oligocene period of seawater influx into the volcanic pile. Because all of the overlying sediments are younger, the 54-Ma age of formation of most of the celadonites, and the intergrown calcite, precludes the possibility that the secondary minerals originally formed from seawater that had evolved to lower ${ }^{18} \mathrm{O}$ content by diagenesis of a thick, over-lying sediment pile (c.f. Lawrence and Gieskes, 1981). This, and the fact that there is no $\mathrm{Sr}$ isotopic evidence of secondary mineral formation from continental waters, constrains the source of oxygen in the secondary clays and carbonates: we conclude that they formed from seawater, and the oxygen in the carbonates reequilibrated at lower temperatures.

We cannot distinguish whether oxygen in the secondary carbonates reequilibrated with seawater or evolved pore water, only that it did so at temperatures below the mineral formation temperatures.

\section{CARBON ISOTOPES}

The values of $\delta{ }^{13} \mathrm{C}$ throughout most of the upper series, except the lowest part, are near $-4.0 \%$ (PDE). Generally, minor secondary carbonates in weathered and hydrothermally altered basalts have $\delta{ }^{13} \mathrm{C}$ values of 0 to $+2 \%$ (McKenzie, 1980; Anderson and Lawrence, 1976). Most meteoric water carbonates have $\delta^{13} \mathrm{C}$ in the range -9 to $-3 \%$ (Keith and Weber, 1964; Hudson, 1977). Nevertheless, there is no corroborating evidence that any of the secondary minerals formed from meteoric waters. The negative $\delta{ }^{13} \mathrm{C}$ values in Hole $642 \mathrm{E}$ are uniform over $675 \mathrm{~m}$. Such uniform ${ }^{13} \mathrm{C}$ contents cannot be related to organic carbon contributions from widely scattered interflow sediments, or overlying sediment pore water (c.f. Anderson and Lawrence, 1976). We therefore suggest that the peculiarly low $\delta{ }^{13} \mathrm{C}$ values in secondary carbonates of Hole 642E resulted from a strong input of basaltic or mantle carbon (Fuex and Baker, 1973; Pineau et al., 1976).

Carbonate formation is probably related to interaction of water with the surrounding volcanic rocks and trapped $\mathrm{CO}_{2}$ in the vesicles and fractures. Carbonate fillings having $\delta{ }^{13} \mathrm{C}$ values similar to those noted in the upper parts of Hole 642E have been noted in Hole 504B, DSDP Leg 83, by Alt et al. (1985) and Honnorez et al. (1985), and in Iceland (Hattori and Muehlenbachs, 1982), and are all attributed to mantle carbon contributions., In Hole 504B the $\delta{ }^{13} \mathrm{C}$ of the carbonates decreases steadily with depth; this is attributed to increased contribution of mantle carbon derived either from the degassing of basaltic magmas or leaching from hydrothermally altered basaltic rocks (Alt et al., 1986). However, compared to Hole 642E, Hole 504B penetrated a fossil high temperature alteration system formed at a higher geothermal gradient above a magma chamber (Anderson, Honnorez, Becker, et al., 1985).

Basaltic rock carbon and mantle carbon may be assumed to have the same $\delta{ }^{13} \mathrm{C}$ as carbonatites and diamonds, that being in the narrow range of $-5 \pm 2 \%$ (Deines and Gold, 1973). Ohmoto and Rye (1979) calculate the average isotopic composition of mafic igneous rock carbon from the data of Fuex and Baker (1973) as being $-5.5 \pm 1.5 \%$. Carbon derived from the dissolution of the more abundant oxidized carbon in basalts would dominate the isotopic signature of the related pore fluid; only a small fraction would have come from oxidation of the reduced basaltic carbon. It is quite unlikely that the depleted ${ }^{13} \mathrm{C}$ content of the Hole $642 \mathrm{E}$ secondary carbonates could have been derived from mantle $\mathrm{CO}_{2}$ released by degassing of basaltic magmas. The very depleted values of $\delta{ }^{13} \mathrm{C}$ for carbonates around the 1080 -m level, noteably the ferroan calcites in the lowest $50 \mathrm{~m}$ of the upper series, are most likely due to the incorporation of light carbon found in the rock. This light carbon has been noted in basaltic rocks in the past and had been attributed variously to contamination of basalt by marine organic carbon (Mattey et al., 1984); to Rayleigh fractionation during degassing (Pineau and Javoy, 1983); or to the oxidation and incorporation in carbonates of light carbon from kerogen (McKenzie, 1980; Degens, 1969). The widespread occurrence of carbonates with light $\delta{ }^{13} \mathrm{C}$ values, both in vesicles and fractures at this level in Hole 642E would suggest that these values are probably related to the oxidation of organic matter trapped in the underlying volcaniclastic rocks. The underlying carbonaceous, muddy volcaniclastic beds (Unit S43) provide a ready source of organic matter. The hypothesis that these very light ${ }^{13} \mathrm{C}$ carbonates originated by oxidation of organic carbon is consistent with the red-brown discoloration of the fracture wall rocks in this area. This red-brown discoloration was probably due to precipitation of ferric hydroxides. Values of $\delta{ }^{13} \mathrm{C}$ between $-6.0 \%$ and $-11.5 \%$ found below the $1100-\mathrm{m}$ level in Hole $642 \mathrm{E}$ probably represent mixtures of ${ }^{13} \mathrm{C}$ from the two major carbon pools, oxidized organic carbon and basaltic carbon.

LeHuray and Johnson (this volume) found that celadonites in Flows 17 and 18 had $\mathrm{Rb} / \mathrm{Sr}$ ages of about $25 \mathrm{Ma}$, and ${ }^{87} \mathrm{Sr} /$ ${ }^{86} \mathrm{Sr}$ that indicate a seawater source, and they conclude there was a relatively large influx of seawater at that time. Calcites from Flow 17, however, retain their negative $\delta{ }^{13} \mathrm{C}$ signatures, indicating that carbon in the calcites did not re-equilibrate with seawater at this time.

Very low $\delta{ }^{13} \mathrm{C}$ calcites appear to be rare in oceanic basalts, suggesting that the conditions observed here, in this particular section of Hole 642E, are not common in the oceanic crust.

\section{Water:Rock Ratios during Carbonate Formation}

Many geochemical characteristics of the secondary minerals in Hole $642 \mathrm{E}$ change with position in the flows. Desprairies et al. (this volume) found that the $\mathrm{Fe}^{2+} / \mathrm{Fe}^{3+}$ ratio of saponites increased toward the centers, and they suggested this resulted from continuous extraction of oxygen from inflowing seawater during development of the clay minerals. Desprairies et al. found no systematic changes in the $\delta{ }^{18} \mathrm{O}$ of clay minerals in Hole $642 \mathrm{E}$ that were dependent on within-flow position. However, in samples from Leg 81, Rockall Plateau, Desprairies et al. (op. cit.) did in fact find that the $\delta^{18} \mathrm{O}$ of the clay minerals varied according to their position within flows (op. cit., Table 6) such that their temperatures of formation were higher in the flow interiors, or the $\delta{ }^{18} \mathrm{O}$ of the fluid was depleted towards the flow interior. Similarly, LeHuray and Johnson (Table 1, this volume) found a correlation between flow position and the $\mathrm{Sr}$ isotopic composition of the whole rocks. They found lower ${ }^{87} \mathrm{Sr} /{ }^{86} \mathrm{Sr}$ initial ratios in samples from flow centers, and conclude that the flow centers contained no significant seawater $\mathrm{Sr}$, as a result of lower water:rock ratios in the less-permeable flow centers. LeHuray and Johnson found, however, that the basaltic $\mathrm{Sr}$ contribution to most smectites and calcites was small, and calcite, or smectite ${ }^{87} \mathrm{Sr} /{ }^{86} \mathrm{Sr}$ did not correlate with position in flows.

As a result of all of these findings we have looked for similar variations, related to position within flows, in ${ }^{13} \mathrm{C}$ content of calcites from Hole 642E. There is a great deal of scatter in the data, and certainly no good correlation, but it is worth noting here that the lowest $\delta{ }^{13} \mathrm{C}$ values are from flow centers.

Since unaltered basalts contain greater than an order of magnitude more carbon than seawater (Fuex and Baker, 1973; Turekian, 1968) it is not unreasonable to suggest that small amounts of water within the basalt pile could achieve a ${ }^{13} \mathrm{C}$ content ap- 
proaching that of basalt, assuming enough time for isotopic equilibrium between the fluid and rock. At water:rock ratios of about 10:1 the contributions of seawater carbon and basaltic carbon to the overall ${ }^{13} \mathrm{C}$ content of the fluid would be about equal. Because the carbon isotopic system preserved in Hole $642 \mathrm{E}$ was dominated by basaltic carbon, the water:rock ratios must have been lower than 10:1 at the time of carbonate formation.

\section{GEOTHERMAL GRADIENTS}

For Site 555 on Rockall Plateau, Harrison and Merriman (1984) estimated a paleogeothermal gradient in the range 1000 to $300^{\circ} \mathrm{C} / \mathrm{km}$, based on alteration mineralogy. In contrast, we estimate the paleogeothermal gradient for Hole $642 \mathrm{E}$, based on saponite oxygen isotope geothermometer temperatures calculated by Desprairies et al. (this volume), to be about $150^{\circ} \mathrm{C} / \mathrm{km}$. Geothermal gradients in the range of 50 to $90^{\circ} \mathrm{C} / \mathrm{km}$ are suggested by oxygen isotope fractionation in carbonates in Hole 642E (Table 3). These lower geothermal gradients are appropriate for 50 to $60 \mathrm{Ma}$ oceanic crust (Parsons and Sclater, 1977), and are consistent with the present-day geothermal gradients in both Hole $642 \mathrm{E}\left(67.6^{\circ} \mathrm{C} / \mathrm{km}\right.$; E. Taylor, pers. commun.) and on Rockall Plateau (Roberts et al., 1984). The oxygen isotopes in carbonates re-equilibrated at a geothermal gradient that was lower than that during the formation of the saponites, indicating, not unexpectedly, that the geothermal gradient on the Vøring Plateau decreased with time.

\section{CONCLUSIONS}

We interpret our results as indicating that the majority of the calcites were precipitated from relatively cool seawater percolating through the basalt pile at low water:rock ratios. The slightly negative $\delta{ }^{13} \mathrm{C}$ values in carbonates from most of the upper series resulted from precipitation from fluids buffered by the carbon isotopic composition of the host rock. Oxygen, being much more abundant than carbon in the water, and also more abundant in the water than in the host rock, retained the isotopic signature of seawater and was not buffered by the rock. The progressive depletion in the $\delta{ }^{18} \mathrm{O}$ values is taken to indicate increasing equilibration temperatures with depth, but not temperatures of formation. Oxygen, but not carbon, isotopes in the secondary carbonates re-equilibrated after formation.

The most logical sequence of secondary mineral-forming events is one of decreasing temperature through time. The events we recognize are: (a) the formation of saponite at relatively high temperatures; (b) celadonite and calcite development at somewhat lower temperatures and water:rock ratios of less than 10:1 during seawater incursion at about $54 \mathrm{Ma}$, and (c) later re-equilibration of the oxygen isotopes but not carbon isotopes in calcite. The latter may have accompanied the formation of some new celadonite or $\mathrm{Sr}$ re-equilibration in some celadonites.

We cannot distinguish whether oxygen in the secondary carbonates re-equilibrated with seawater or evolved pore water, only that it re-equilibrated at temperatures below those of formation.

Oxygen in the carbonates reequilibrated isotopically at a lower geothermal gradient than that at which the saponites formed. The geothermal gradient on the Vøring Plateau decreased with time.

There is no evidence of an earlier mineralization event involving the convective circulation of freshwater, comparable to that seen in present-day Iceland. Perhaps this is because most of the cored section of lavas formed distant from a volcanic center, as could be interpreted from the absence of dykes and felsic units in the upper series.

\section{ACKNOWLEDGMENTS}

The authors are grateful to the staff of the University of Waterloo Stable Isotope Laboratory, particularly R. Drimmie. We also thank James Lawrence and other ODP reviewers for their thoughtful and thought-provoking comments and criticisms of an earlier draft of this paper.

\section{REFERENCES}

Alt, J. C., Laverne, C., and Muehlenbachs, K., 1985. Alteration of the upper oceanic crust: mineralogy and processes in Deep Sea Drilling Project Hole 504B, Leg 83. In R. N. Anderson, J. Honnorez, K. Becker et al. (Eds.), Init. Repts. DSDP, 83: Washington (U.S. Government Printing Office), 217-247.

Alt, J. C., Muehlenbachs, K., and Honnorez, J., 1986. An oxygen isotopic profile through the upper kilometer of the oceanic crust, DSDP Hole 504B, Earth Planet. Sci. Lett., 80:217-229.

Anderson, R. N., Becker, K., Honnorez, J., et al. (Eds.), 1985. Init. Repts. DSDP, 83: Washington (U.S. Government Printing Office).

Anderson, T. F., and Lawrence, J. R., 1976. Stable isotope investigations of sediments, basalts, and authigenic phases from Leg 35 cores. In Hollister, C. D., and Craddock, C., et al., Init. Repts. DSDP, 35: Washington (U.S. Government Printing Office), 497506.

Arnason, B., 1976. Groundwater System in Iceland, Traced by Deuterium: Reykjavik, Iceland (Visindafelag Islendinga).

Degens, E. T., 1969. Biogeochemistry of stable carbon isotopes. In Eglinton, G., and Murphy, M.T.J. (Eds.), Organic Chemistry: New York (Springer-Verlag), 304-329.

Deines, P., and Gold, D. P., 1973. The isotopic composition of carbonatite and kimberlite carbonates and their bearing on the isotopic composition of deep seated carbon, Geochim. Cosmochim. Acta, 37:1709-1733.

Eldholm, O., Thiede, J., and Taylor, E., 1987. Evolution of the Norwegian Continental Margin: Background and Objectives. In Eldholm, O., Thiede, J., Taylor, E., et al., Proc. ODP, Init. Repts, 104: College Station, TX (Ocean Drilling Program), 5-25.

Fuex, A. N., and Baker, D. R., 1973. Stable carbon isotopes in selected granitic, mafic and ultramafic igneous rocks. Geochim. Cosmochim, Acta, 37:2509-2521.

Gieskes, J. M., Lawrence, J. R., and Galleisky, G., 1978. Interstitial water studies, Leg 38. In Talwani, M., Udintsev, G., et al. (Eds.), Init. Repts. DSDP, Suppl., Vols. 38 to 41: Washington (U.S. Govt. Printing Office), 121-134.

Harrison, R. K., and Merriman, R. J., 1984. Petrology, mineralogy, and chemistry of basaltic rocks: Leg 81 . In Roberts, D. G., Schnitker, D., et al. (Eds.), Init. Repts. DSDP, 81: Washington (U.S. Govt. Printing Office), 743-774.

Hattori, K., and Muehlenbachs, K., 1982. Oxygen isotope ratios of the Icelandic crust. J. Geophys. Res., 87:6559-6565.

Hesse, R., 1986. Early diagenetic porewater/sediment interaction: modern offshore basins, Geoscience Canada, 13:165-196.

Hinz, K., Dostman, H. J., and Hanisch, J., 1984. Structural elements of the Norwegian continental margin. Geol. Jahrb., A75:193-221.

Honnorez, J., Alt., J. C., Honnerez-Guerstein, B. M., Laverne, C., Muehlenbachs, K., Ruiz, J., and Saltzman, E., 1985. Stockworklike sulfide mineralization in young oceanic crust; Deep Sea Drilling Project Hole 504B. In Honnorez, J., Anderson, R. N., et al. (Eds.), Init. Repts. DSDP, 83: Washington (U.S. Govt. Printing Office), 263-282.

Hudson, J. D., 1977. Stable isotopes and limestone lithification. $Q . J$. Geol. Soc. London, 133:637-660.

Keith, M. L., and Weber, J. N., 1964. Isotopic composition and environmental classification of selected limestones and fossiles. Geochim. Cosmochim. Acta, 28:1787-1816.

Lawrence, J. R., Gieskes, J. M., and Broecker, W. S., 1975. Oxygen isotope and cation composition of DSDP pore water and the alteration of Layer II basalts, Earth Planet. Sci. Lett. 27:1-10.

Lawrence, J. R., Gieskes, J. M., and Anderson, T. F., 1976. Oxygen isotope material balances calculations, Leg 35. In Hollister, C. D., and Craddock, C., et al., (Eds.), Init. Repts. DSDP, 35: Washington (U.S. Govt. Printing Office), 507-512. 
Lawrence, J. R. and Drever, J. I., 1981. Evidence for cold water circulation at DSDP Site 395: isotopes and chemistry of alteration products. J. Geophys. Res., 86:5125-5133.

Lawrence, J. R., and Gieskes, J. M., 1981. Constraints on water transport and alteration in the oceanic crust from the isotopic composition of porewater. J. Geophys. Res., 86:7924-7934.

Longstaffe, F. J., 1983. Stable isotope studies of diagenesis in clastic rocks. Geoscience Canada, 10:43-58.

Mattey, D. P., Carr, R. H., Wright, I. P. and Pillinger, C. T., 1985. Carbon isotopes in submarine basalts. Earth Planet. Sci. Lett., 70:196206.

McCrea, J. M., 1950. On the isotopic chemistry of carbonates and paleotemperature scale. J. Chem. Phys., 18:849-857.

McKenzie, J., 1980. Stable isotopic study of carbonate minerals from the basalt flows on Suiko Seamount: DSDP Leg 55 Hole 433C. In Jackson, E. D., Koisumi, I., et al. (Eds.), Init. Repts. DSDP, 55: Washington (U.S. Govt. Printing Office), 653-657.

Muehlenbachs, K., 1977. Oxygen isotope geochemistry of DSDP Leg 37 rocks. In Aumento, F., Melson, W. G., et al. (Eds.), Init. Repts. DSDP, 37: Washington (U.S. Govt. Printing Office), 617-619.

Mutter, J. C., Talwani, M., and Stoffa, P. L., 1982. Origin of the seaward dipping reflectors in oceanic crust off the Norwegian margin by "subaerial sea-floor spreading." Geology, 10:353-357.

Ohmoto, H. and Rye, R. O., 1979. Isotopes of sulphur and carbon. In Barnes, H. L. (Ed.), Geochemistry of Hydrothermal Ore Deposits: New York (John Wiley and Sons, Inc.), 509-567.

O'Neil, J. R., Clayon, R. N., and Mayeda, T. K., 1969. Oxygen isotope fractionation in divalent metal carbonates. J. Chem. Phys., 51: 5547-5558.

Parsons, B. and Sclater, J. G., 1977. An analysis of the variation of ocean floor bathymetry and heat flow with age. J. Geophy. Res., 81: 2997-3006.

Pineau, F., and Javoy, M., 1983. Carbon isotopes and concentrations in mid-oceanic ridge basalts. Earth Planet. Sci. Lett., 62:239-257.

Pineau, F., Javoy, M., and Bottinga, Y., 1976. ${ }^{13} \mathrm{C} /{ }^{12} \mathrm{C}$ ratios of rocks and inclusions in popping rocks of the Mid-Atlantic Ridge: their bearing on the problem of deep seated carbon. Earth Planet. Sci. Lett., 29:413-321.

Roberts, D. G., Backman, J., Morton, A. C., Murray, J. W., and Keene, J. B., 1984. Evolution of volcanic rifted margins: synthesis of Leg 81 results on the west margin of Rockall Plateau. In Roberts, D. G., Schnitker, D., et al., Init. Repts. DSDP, 81: Washington (U.S. Govt. Printing Office), 883-912.

Savin, S. M., Douglas, R. G., Keller, G., Killingley, J. S., Shaughnessy, L., Sommer, M. A., Vincent, E., and Woodruf, F., 1981. Miocene benthic foraminiferal isotope records: a synthesis. Mar. Micropaleontol., 6:423-450.

Shipboard Scientific Party, 1986. Leg 104, Scientific drilling in the Norwegian Sea. Nature, 319:360-361.

Shipboard Scientific Party, 1987. Site 642: Norwegian Sea. In Eldholm, O., Thiede, J., Taylor, E., et al., Proc. ODP, Init. Repts., 104: College Station, TX (Ocean Drilling Program), 82-112.

Talwani, M., Mutter, J. C., and Hinz, K., 1983. Ocean Continent boundary under the Norwegian continental margin. In Bott, M.H. P., et al. (Eds.), Structure and development of the GreenlandScotland Ridge: New York (Plenum Press), 121-131.

Taylor, H. P., 1979. Oxygen and Hydrogen isotope relationships in hydrothermal mineral deposits. In Barnes, H. L. (Ed.), Geochemistry of Hydrothermal Ore Deposits: New York (John Wiley and Sons, Inc.), 236-277, 509-567.

Turekian, K. K., 1968. Oceans: Englewood Cliffs, N.J., (Prentice-Hall, Inc.), 92.

Vink, G. E., 1984. A hotspot model for Iceland and the Vøring Plateau. J. Geophys. Res., 89:9949-9959.

Yeh, H. W., and Savin, S. M., 1977. Mechanism of burial metamorphism of argillaceous sediments: 3.0-isotope evidence. Geol. Soc. Am. Bull., 88:1321-1330.

Date of initial receipt: 27 March 1987

Date of acceptance: 15 April 1988

Ms 104B-140 